DOI 10.2478/v10040-008-0132-5

\title{
PREDICTION OF SHIP PERFORMANCE IN THE RISK BASED DSS BEDS IN SafePort EUROPEAN PROJECT
}

\section{PROGNOZA ZACHOWANIA SIE STATKU W SWD BEDS OPARTYM NA ANALIZIE RYZYKA W PROJEKCIE EUROPEJSKIM SafePort}

\author{
Teresa Abramowicz-Gerigk ${ }^{1}$, Zbigniew Burciu ${ }^{2}$ \\ (1) Gdynia Maritime University, Faculty of Navigation \\ Al. Jana Pawla II 3, 81-345 Gdynia, Poland \\ (2) Gdynia Maritime University, Faculty of Navigation \\ Al. Jana Pawla II 3, 81-345 Gdynia, Poland \\ E-mails: (1) tagerigk@am.gdynia.pl (2) zbj@am.gdynia.pl
}

Abstract: The paper presents the program of experimental investigations of ship performance prepared to obtain and confirm the models introduced in decision support system BEDS (Berthing and Entry Decision Support System) developed within SafePort European Project. Copyright (C) 2010 Journal of KONBiN.

Keywords: model and full scale experiment, ship performance, DSS

Streszczenie. $W$ artykule przedstawiono program badań eksperymentalnych zachowania sie statku przygotowany $w$ celu opracowania $i$ weryfikacji modeli zastosowanych $w$ systemie wspomagania decyzji BEDS (Berthing and Entry Decision Support System), opracowanym $w$ ramach projektu europejskiego SafePort.

Stowa kluczowe: badania modelowe i rzeczywiste statku, SWD 


\section{Introduction}

The paper presents the program of experimental investigations developed for modelling the ship performance during harbour manoeuvres. The obtained models will be implemented in decision support system BEDS Berthing and Entry Decision Support system - developed within SafePort European Project.

Safe Port is a collaborative research project of an interdisciplinary consortium of six Polish and Norwegian partner institutions of different areas in maritime technology within ERA-NET MARTEC - Maritime Technologies European initiative.

The main objectives of the project are development of a hydrometeorological information system based on real time measurements and hydro-meteorological models and development of designed for ferries decision support system BEDS as an element of Port ITS.

The decision support system BEDS is based on the theory of stochastic processes and risk analysis. It will enable sharing of the most essential environmental information to all active parties in the harbour area and supports the navigational decisions of Ship Master and Harbour Master increasing safety and efficiency of manoeuvring operations.

To determine a complex safety measure for the manoeuvring operations along the approach channel and during ship berthing and unberthing it is necessary to predict wind, waves, sea current and restricted waters effects on ship performance.

Along the real time information about weather and traffic the prediction models must be used. Statistical emulator will provide the necessary estimates determining the most probable circulation patterns from the actual atmospheric forcing field.

The models of ship motion, used in BEDS system must have higher accuracy than the generally accepted models in the applications used for design and training. For this reason the mathematical models should be developed and validated by the set of experiments. The program of model tests for ship motion prediction has been developed for the large man manned model of a car - passenger ferry. The ship berth interaction during berthing/unberthing was predicted using CFD methods and the measurements of pressure distribution on the quay wall generated by propellers and thrusters for the real ship were proposed. 


\section{BEDS system}

\subsection{General assumptions of BEDS system}

The decision support system consists of four modules: safety module, transmission/communication module, display/information device and ship response module. The safety module consists of the following sub-modules: identification of external conditions - weather and traffic, hazard identification and risk assessment.

The ship response module collects the online data of ship performance. The data is transferred to the safety module allows for the online hazards identification and risk prediction. The system is presented in Figure 1 (Abramowicz-Gerigk, 2008b). Display and information device introduces the Ship Virtual Mask (SVM) on the electronic chart, showing the risk of the navigational situation and possible risk mitigation measures.

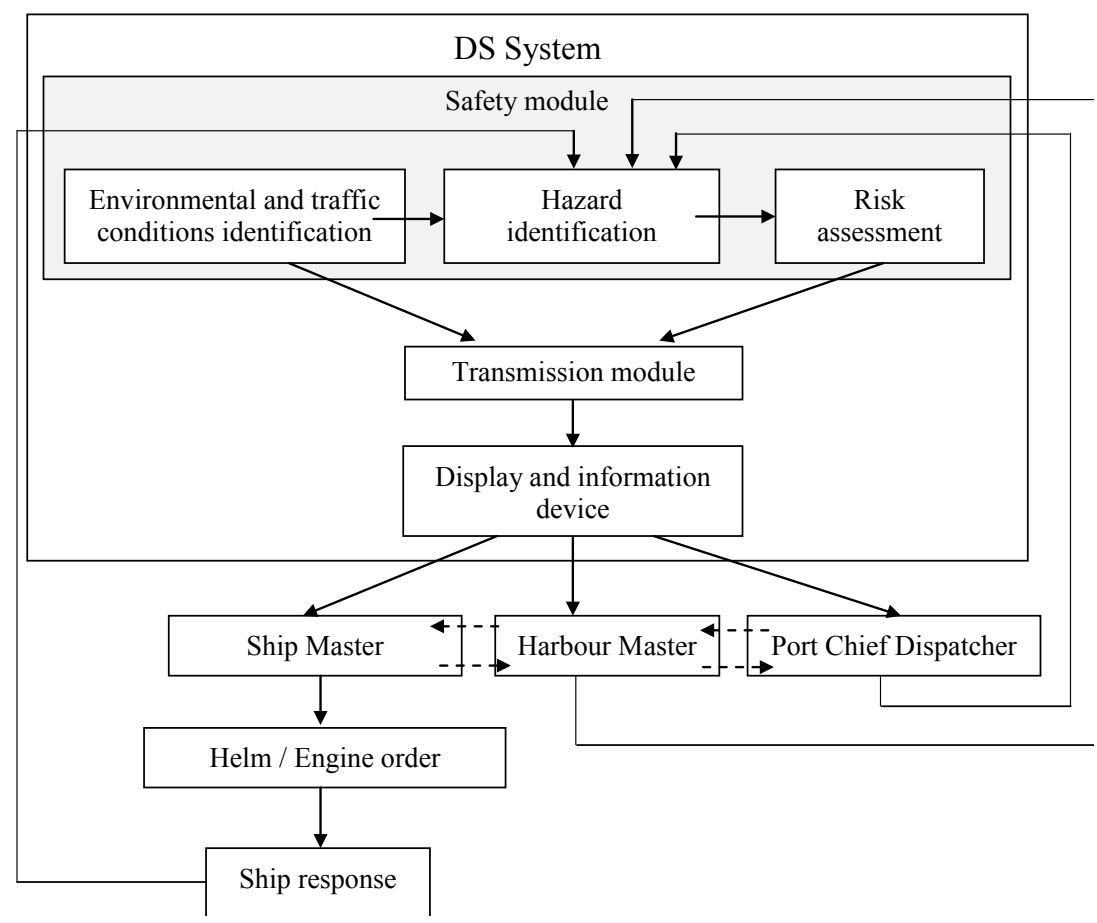

Fig. 1 Decision support system BEDS (Abramowicz-Gerigk, 2008b). 
The metocean monitoring will mainly serve for combating local marine pollution and tracking the drifting objects more efficiently. The hydrometeorological data from the system will be collected into a data base and serve the purpose of explaining long and short term changes in the marine environment (currents, waves, water level, salinity, temperature and oxygen).

Hazard identification module is a set of procedures for computing the online information of the possible hazards based on real and predicted ship performance. For the identified hazards the probability and consequences are calculated in the risk assessment module and the information about the risk mitigation measures is available for ship master and harbour master. The hazard identification module is presented in Figure 2. The internal and external hazards are analysed.

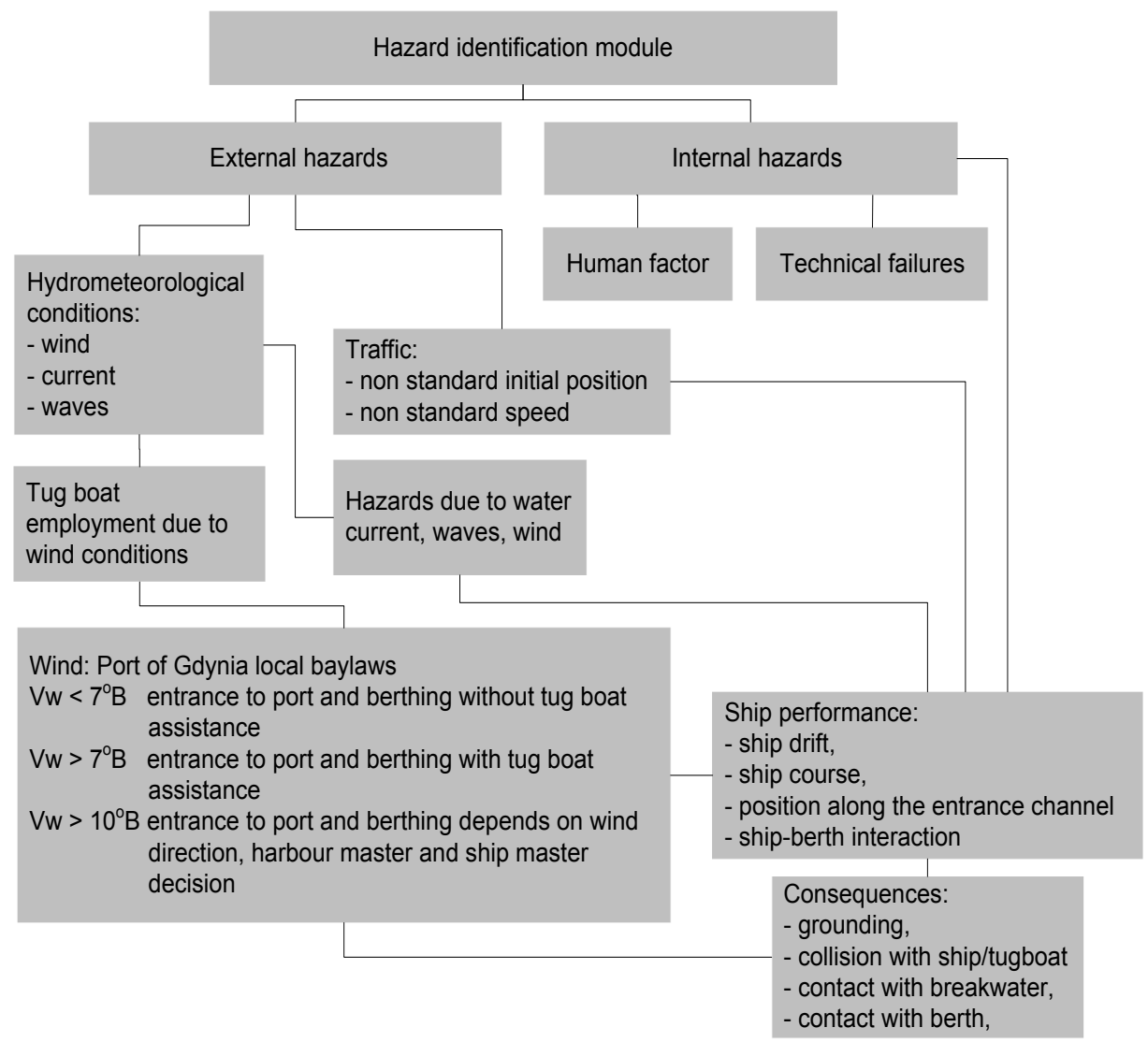

Fig. 2 Hazard identification module of decision support system BEDS. 
The external hazards are identified with respect to traffic and hydrometeorological conditions. The hydrometeorological conditions and tug boat employment determine ship performance during berthing and navigation along the approach channel. The initial position and speed are considered. The internal hazards are the human factor and technical failures. The technical failures have the direct influence on ship performance, they are not analysed by the system and the risk mitigation measures are applied with respect to the online decisions of the ship master and harbour master.

\subsection{Models of ship performance in BEDS system}

The input data of the ship performance models are the online information of hydrometeorological parameters in time and space domain (Burciu, 2003) and ship motion parameters. The stochastic wind, wave and current models provide a practical basis for ship performance analysis. The variable spectral shape assumed in these models can have a considerable influence on the performance prediction. The approach uses wind, wave and current transfer functions and relates the wave, wind and current parameters to the particular motion component: surge, sway and yaw.

The models used in hazard identification module are presented in Figure 3.

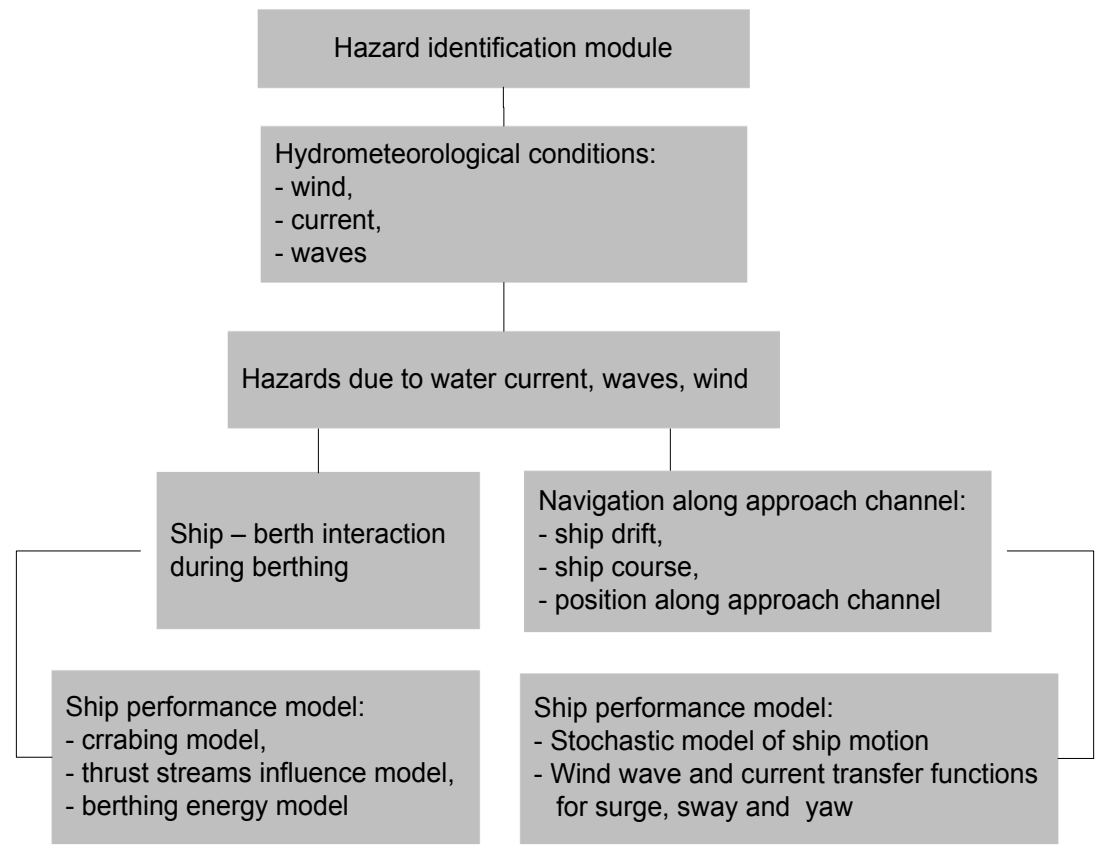

Fig. 3 Models used in hazard identification module of BEDS system. 
The model of ship motion used to determine ship performance along the approach channel $t$ include wind, wave and sea current excitation forces. In a vector form the equations of ship motion can be expressed in ship-fixed coordinate system with the origin at the ship's centre of gravity and the Earth-fixed coordinate system as follows (Perez et al., 2004; Domachowski \& Ghaemi, 2007):

$$
\begin{gathered}
\mathbf{M} \dot{v}+\mathbf{C}(v) v+\mathbf{D}(v) v+\mathbf{g}(\eta)=\tau \\
\dot{\eta}=\mathbf{J}(\eta) v
\end{gathered}
$$

Where $\eta=\left[\begin{array}{lll}x & y & \psi\end{array}\right]^{\mathrm{T}}$ is vector of ship position and course - in horizontal plane; $v=\left[\begin{array}{lll}\mathrm{u} & \mathrm{r}\end{array}\right]^{\mathrm{T}}$ - vector of velocities in horizontal plane; $\mathrm{J}$ - kinematic transformation matrix; M, C and D denote the system inertia, Coriolis and damping matrices; $\mathrm{g}$ - vector of gravitational and buoyancy forces and moments; $\tau$ - vector of external forces and moments.

The relations between sea elevation, wind speed, current velocity and ship motion components are based on stochastic mathematical description of the phenomena, using the transfer functions.

The example of the unified model of ship manoeuvring in seaway (Perez et al., 2004) is presented in Figure 4, where FTF represents the wave excitation forces per unit of wave amplitude.

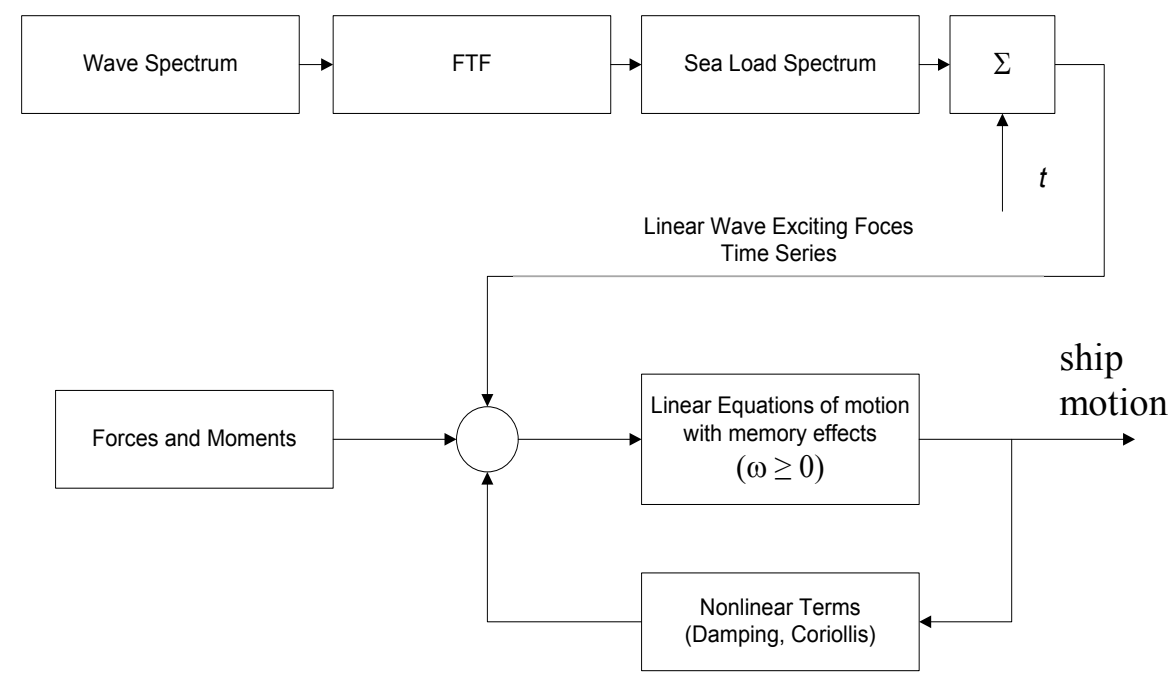

Fig. 3 Unified model of ship manoeuvring. 
Model tests and CFD calculations will be used to predict transfer functions for wave, wind and current forces generated on a hull.

The mathematical model will be validated by realization of a set of experiments performed on large man manned model of a car - passenger ferry. The model tests will be conducted at the Ship Handling Research and Training Centre of Foundation for Safety of Navigation and Environment Protection, in the lake Silm at Ilawa-Kamionka, Poland. The model used for experiments is equipped with the necessary devices simulating ship systems and the basic navigational aids present onboard real ships.

The ship - berth interaction model is based on reliability analysis of berth and sea bottom protection. The ship motion model to determine crabbing in different wind conditions including ship - berth interaction forces is determined on the basis of model tests (Abramowicz-Gerigk, 2008a).

\section{Experimental investigation of ship performance}

\subsection{Model tests}

The open water experimental test setup in the lake Silm consists of the scale model of the approach fairway, port entrance and ferry terminal scaled down from the layout of Port of Gdynia. Some of the model test of ship performance have been already finished, some have begun and will be continued.
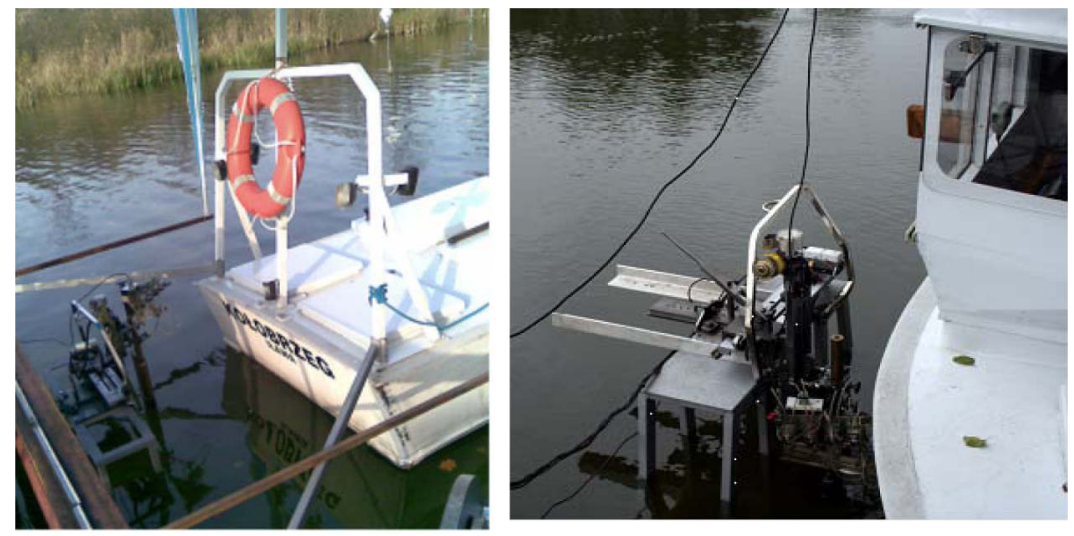

Fig. 4 Experimental test setup for the mmeasurements of bow thrusters and propellers thrust streams. 
The model tests will be conducted using the man manned scale model of the car-passenger ferry in 1:16 scale, wave and current generators, having capacity to create similar to the real site conditions and onboard wind simulator.

The tests will be conducted in the selected environmental conditions and will include the following manoeuvres:

- harbour approach (fairway navigation),

- harbour entry

- berthing / unberthing in the ferry terminal.

The model's trajectory will be measured by a very precise GPS system working in RTK mode along with the wind, current and wave parameters. Verification of the models used in the system is based on the comparison of the prediction based on the stochastic model of ship controllability and model tests results.

Measurements of ship - pier interaction with respect to the influence of the thrusters outflow streams and propellers thrust streams on the pier and sea bottom protection in the berthing area are based on the CFD prediction of the flow field generated by the berthing/unberthing vessel and the measurements of the thrusters outflow streams on the physical model. The experimental test setup is presented in Figure 4. For the presented measurements of the propeller jet a multi-hole pressure probe was used.

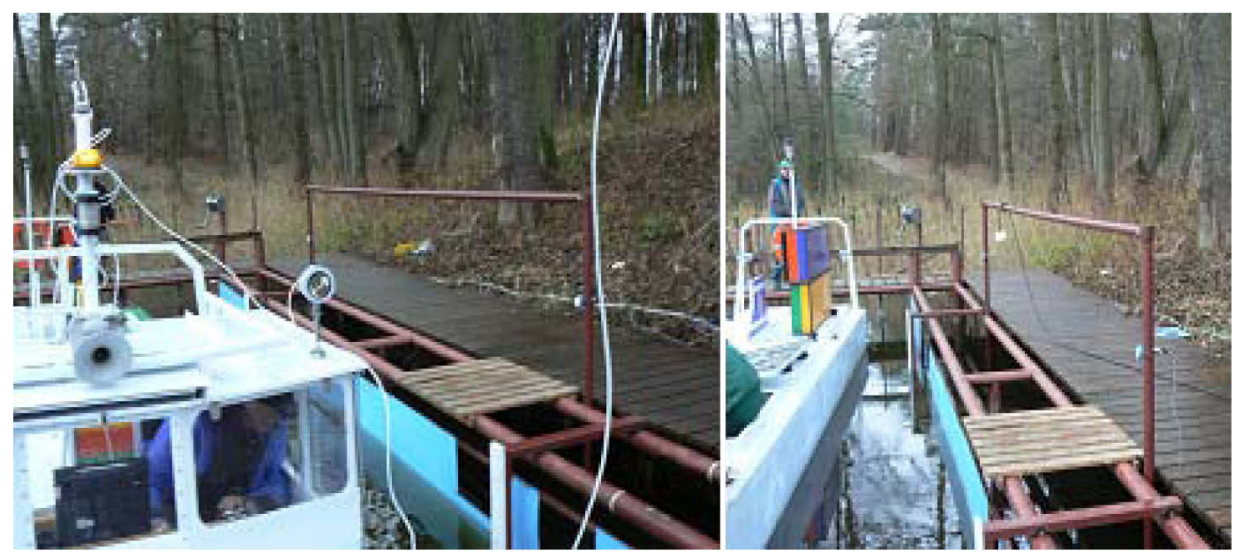

Fig. 5 Experimental test setup for the measurements of the motion parameters during crabbing manoeuvre. 
The mathematical model of ship crabbing which includes ship - berth interaction forces was tested in open water conditions using ultrasound rangefinders. The experimental facility is presented in Figure 5.

\subsection{Real scale experiments}

The real scale tests include the physical modelling of the environmental factors: waves and current field.

Real scale measurements of ship - pier interaction consists of installation of measuring devices on the pier construction and sea bottom and measurements of pressure loads induced by self-manoeuvring vessel in real conditions.

\section{Conclusions}

SafePort project supports the European e-maritime initiative - a concept of a virtual network in an electronic environment based on the open platform and standards ensuring interoperability between different maritime-related applications. BEDS system can be used by the existing and new build ICT systems, logistic centres and Intelligent Transportation Systems (ITS) (Abramowicz-Gerigk T., Burciu Z., 2009).

Acknowledgment

The paper presents a part of results of two research projects:

1. "Safety of berthing of the vessel in MOS transportation system" - project sponsored by Polish Ministry of Science and Higher Education:, conducted at Gdynia Maritime University, Poland. The open water model tests were carried out in collaboration with Ship Handling Research and Training Centre of the Foundation for Safety of Navigation and Environment Protection in Ilawa-Kamionka and Ship Design and Research Centre S.A, Poland.

2. "Safe Port Entry and Berthing Ship and Port Advising System as an Element of Port ITS" - project within ERA-NET MARTEC European Initiative, part conducted at Gdynia Maritime University, Poland, sponsored by Polish Ministry of Science and Higher Education. 


\section{References}

1. Abramowicz-Gerigk T. a: Experimental study on the hydrodynamic forces induced by a twin-propeller ferry during berthing. Ocean Engineering. Elsevier. Volume 35, Issues 3-4, p. 323-332, March 2008;

2. Abramowicz-Gerigk T. b: Elements of port ITS increasing safety and efficiency of ship manoeuvring operations in short sea shipping. Journal of KONBIN, Vol. 1 No 1(4) 2008. p. 71-81,Wrocław 2008;

3. Abramowicz-Gerigk T., Burciu Z. Ryzyko dynamiczne operacji manewrowych promów. Problemy Eksploatacji Nr 4/2009, p. 115-125, 2009;

4. Burciu Z. The model of surface currents field as an element of determining search domain, 6th IFAC Conference on Maneuvering and Control of Marine Crafts, Institute of Informatics and Applications (II A), University of Girona, Catalonia, Spain Joan Batlle, Mogens Blanke Girona, Spain, p.108-112, 2003;

5. Abramowicz-Gerigk T., Burciu Z. Systemy bezpieczeństwa i obstugi autostrady morskiej. Prace Naukowe, Transport, zeszyt 70, Modelowanie Procesów Transportowych cz. 2, Oficyna Wydawnicza Politechniki Warszawskiej, p. 5-21, 2009;

6. Domachowski Z., Ghaemi M. H. Okrętowe uktady automatyki. Wydawnictwo Politechniki Gdańskiej. Gdańsk 2007;

7. Perez T., Fossen T. I., Sorensen A. A discussion about seakeeping and manoeuvring models. Technical report MSS-TR-001. NTNU, Trondhaim, Norway, http://www.itk.ntnu.no/ ansatte/ Fossen_Thor/papers, 2004;

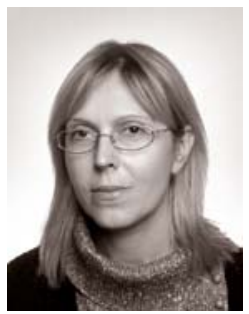

Teresa Abramowicz-Gerigk PhD. Eng., Gdynia Maritime University, Faculty of Navigation. Specialist in ship dynamics and safety of maritime transportation. Several publications in the field of ship hydrodynamics and maritime safety. Member of SSRwT KT Polish Academy of Sciences.

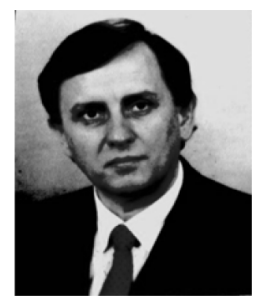

Zbigniew Burciu Prof., is a professor of Gdynia Maritime University, DSc. in transport, safety and reliability in transport. V-ce Dean of Navigational Department. Main subjects of research are the maritime transport safety and Search and Rescue at Sea. Author and co-author of app.100 scientific publications in Polish and English. Master Mariner. 